\title{
Evolution of acute lower respiratory infection in children aged $<5$ years in Morocco from 2005 to 2014
}

Nada Bennani Mechita, ${ }^{1}$ Rachid Razine ${ }^{1,2}$ Majdouline Obtel, ${ }^{1,2}$ Abdelilah Elmarnissi, ${ }^{3}$ Laila Lahlou, ${ }^{1,2}$ Imad Cherkaoui, ${ }^{4}$ Aziza Lyaghfouri, ${ }^{5}$ Mustapha Mrabet ${ }^{1}$ and Redouane Abouqal ${ }^{2,6}$

${ }^{1}$ Laboratory of Biostatistics, Clinical and Epidemiological Research, Faculty of Medicine and Pharmacy, Mohamed V University, Rabat, Morocco (Correspondence to: N. Mechita: nadaben7@gmail.com). ${ }^{2}$ Laboratory of Public Health, Faculty of Medicine and Pharmacy, Mohamed V University, Rabat, Morocco. ${ }^{3}$ Directorate of Planning and Financial Resources. Ministry of Health, Rabat, Morocco. ${ }^{4}$ Directorate of Epidemiology and Disease Control, Ministry of Health, Rabat, Morocco. ${ }^{5}$ Directorate of Population, Ministry of Health, Rabat, Morocco. ${ }^{6}$ Medical Emergency Department, Ibn Sina University Hospital, Rabat, Morocco

\begin{abstract}
Background: Acute lower respiratory infection is a major cause of death in children aged < 5 years in Morocco. The 13 -valent pneumococcal conjugate vaccine (PCV) was introduced to the Moroccan National Immunization Programme in 2010. Aims: To investigate the trend in the incidence of acute lower respiratory infection in children aged $<5$ years during 2005-2014 in Morocco.

Methods: Data on acute lower respiratory infection in children aged $<5$ years were obtained from the data published annually by the Moroccan Ministry of Health. We used joinpoint regression analysis to estimate the trend in incidence of acute lower respiratory infection during the study period.

Results: The incidence of acute lower respiratory infection increased significantly between 2005 and 2011 : by $3.08 \%$ annually in children aged < 5 years and by $3.24 \%$ annually in children aged 1 to $<5$ years. However, the incidence was stable after 2011 as the observed trends were not significant, although the incidence decreased from 2011 to 2014 by $4.26 \%$ annually in children aged < 5 years, by $3.57 \%$ annually in children aged 1 to $<5$ years and by $5.14 \%$ annually in urban areas.

Conclusions: Our results suggest a probable influence of the PCV on the trend in incidence of acute lower respiratory infection in Morocco.

Keywords: acute lower respiratory infection, pneumococcal conjugate vaccine, children, joinpoint regression, Morocco

Citation: Mechita N; Razine R; Obtel M; Elmarnissi A; Lahlou L; Cherkaoui I; et al. Evolution of acute lower respiratory infection in children aged < 5 years in Morocco from 2005 to 2014. East Mediterr Health J. 2021;27(4):373-380. https://doi.org/10.26719/emhj.20.122

Received: 25/07/19; accepted: 07/04/20

Copyright (c) World Health Organization (WHO) 2021. Open Access. Some rights reserved. This work is available under the CC BY-NC-SA 3.o IGO license (https://creativecommons.org/licenses/by-nc-sa/3.o/igo)
\end{abstract}

\section{Introduction}

Acute lower respiratory infections (ALRIs), such as pneumonia and bronchiolitis, are the leading cause of morbidity and mortality in children aged $<5$ years. According to recent estimates, every year about 120-156 million cases of ALRI occur globally, with $\sim 1.4$ million resulting in death. More than $95 \%$ of these deaths occur in low- and middle-income countries (1-3).

ALRI is caused by a number of infective agents, with Streptococcus pneumoniae being the most frequently identified bacterium and respiratory syncytial virus the most common virus (4). S. pneumoniae is responsible for a large proportion of the morbidity and mortality burden worldwide (1). It causes a wide range of diseases, from acute upper respiratory tract infections to severe invasive infections such as meningitis and severe pneumonia (1). The Institute for Health Metrics and Evaluation estimated that pneumococcus was responsible for 393000 pneumonia deaths in children younger than 5 years in 2015 (2), and it is the leading cause of bacterial pneumonia, with an estimated 335000 deaths in 2015 (3).

The pneumococcal conjugate vaccine (PCV) was introduced in the United States of America (USA) in 2000, and covered the 7 pneumococcal serotypes circulating in the USA $(4,6 \mathrm{~B}, 9 \mathrm{~V}, 14,18 \mathrm{C}, 19 \mathrm{~F}$ and $23 \mathrm{~F})$. The National Vaccination Program with 7-valent PCV resulted in a marked decrease in the incidence of severe pneumonia and a reduction in hospital mortality from severe pneumonia (4). PCV has also reduced the incidence of pneumonia in unvaccinated populations by reducing colonization of the nasopharynx in vaccinated children (4), and through herd immunity $(5,6)$. Other studies have also shown a reduction in invasive pneumococcal diseases after introduction of PCV $(7,8)$.

In Morocco, ALRI is a major cause of death in children aged $<5$ years (9). In view of the importance of these infections, Morocco set up a national programme in 1993 to control acute respiratory infections in children. In 1997, the Moroccan Ministry of Health began progressively implementing the World Health Organization's Integrated Management of Childhood Illness (IMCI) strategy. The strategy promotes the use among health workers of evidence-based clinical guidelines in outpatient settings by using standardized clinical case definitions to identify and treat common causes of childhood death. In firstlevel health facilities, the clinical case definition of pneumonia, which is the main cause of ALRI, is based on 
2 simple clinical endpoints: fast breathing and drawing in of the lower chest wall (10). The PCV was introduced in the Moroccan National Immunization Programme in 2010 (9); the 13-valent PCV was introduced in October 2010 and was replaced by 10-valent PCV in July 2012 (11,12). The vaccination consists of 3 injections: the first at 2 months, the second at 4 months and the third at 12 months. PCV coverage was 15\% in 2010, 23\% in 2011 and reached $70-80 \%$ from 2012 (data from the Moroccan Ministry of Health).

The aim of the present study was to investigate the trend in incidence of ALRI in children aged $<5$ years between 2005 and 2014 in Morocco.

\section{Methods}

\section{Study design and population}

This study was conducted in Morocco, situated in the northwest of Africa. We considered the administrative division of Morocco into 16 regions (13), as the study concerned the period before the divisional change in 2015 (14). The estimated population of Morocco in 2014 was around 34 million (15), with a life expectancy at birth of 74.8 years (16). About $10 \%$ of the population was aged < 5 years (15). The fertility rate in 2014 was 2.21 births per woman (15).

We conducted a retrospective observational study using data provided by the national programme for controlling acute respiratory infections in children and published annually by the Moroccan Ministry of Health (16). The definition of ALRI was based only on clinical criteria. Cases were mainly reported from public hospitals and public health centres. Private health facilities do not participate much in the surveillance system. All levels of severity of ALRI were reported but unfortunately, we did not have data stratified by stage of severity.

Data on ALRI in children aged < 5 years from 2005 to 2014, as well as the target populations during these years, were collected from the data published annually by the Moroccan Ministry of Health (16). Data on the number of ALRI cases and the target population were collected by region, age group ( $<1$ year and 1 to $<5$ years) and residence (urban and rural).

\section{Statistical analysis}

The trend in ALRI incidence was assessed by regression analysis using Joinpoint Regression Program, version 4.2.0.2. The incidence of ALRI was calculated as the number of reported cases divided by the target population by region according to age group ( $<1$ year or 1 to $<5$ years) and residence (urban or rural). Multiple reports for the same child in the same year were removed by the data provider so that a case was counted only once.

The Joinpoint Regression Program is a statistical software package that computes and analyses nonlinear, piecewise trends of time series. The trend is computed in segments that are connected together at joinpoints. If there are no joinpoints, the trend is flat and displayed as a straight line. Joinpoint uses a Monte Carlo permutation test to detect years when significant changes in rate trends occur (17). The joinpoint regression is different from other similar models, like piecewise regression, because it has the constraint of continuity at the change points, and the choice of the number of joinpoints and their locations is estimated within the model. A distinguishing characteristic of this model is that the minimum and maximum number of joinpoints allowed is arbitrarily set before the analysis, while the final number of joinpoints is not fixed a priori by the researcher, as in a classical piecewise regression model, but it is established on the basis of a statistical criterion.

The software calculates the annual percentage change (APC) and its 95\% confidence interval (CI) for each trend segment. APC is 1 way to characterize trends in incidence rates over time. When the Log Transformation option on the Input File tab is $\ln (\mathrm{y})=\mathrm{xb}$, then the output calculates the estimated APC. With this approach, the incidence rates are assumed to change at a constant percentage of the rate of the previous year (17). For example, if the APC is $1 \%$, and the rate was 50 per 100000 in 1990, the rate was $50-1.01=50.5$ in 1991 and $50.5-1.01=51.005$ in 1992 . Rates that change at a constant percentage every year change linearly on a log scale. For this reason, to estimate the APC for a series of data, the following regression model is used (17):

$\log \left(R_{y}\right)=b_{0}+b_{1} y$ where $\log \left(R_{y}\right)$ is the natural log of the rate in year $y$.

The APC from year $y$ to year $y+1=\left[\frac{R_{y+1}-R_{y}}{R_{y}}\right] \times 100$

$$
\begin{aligned}
& =\frac{\left\{e^{b_{0}+b_{1}(y+1)}-e^{b_{0}+b_{1}(y)}\right\}}{e^{b_{0}+b_{1}(y)}} \times 100 \\
& =\left(e^{b_{1}}-1\right) \times 100
\end{aligned}
$$

It is not always reasonable to expect that a single APC can accurately characterize the trend over an entire series of data. The joinpoint model uses statistical criteria to determine when and how often the APC changes. For incidence rates, it is fit using joined log-linear segments, so each segment can be characterized using an APC. For example, incidence rates may rise gradually (positive APC) for a period of several years, rise sharply for several years after that, and then drop gradually (negative APC) for the next several years. Finding the joinpoint model that best fits the data allows us to determine how long the APC remained constant and when it changed (17).

For any segment with slope $\beta$, the APC is 100 $\{\exp (\beta)-1\}$. The $100(1-\alpha) \%$ confidence limits are (17):

$$
\begin{aligned}
& \text { Lower }=100\left\{\exp \left(\beta-s^{*} t_{d}^{-1}(1-\alpha / 2)\right)-1\right\} \\
& \text { Upper }=100\left\{\exp \left(\beta+s^{*} t_{d}^{-1}(1-\alpha / 2)\right)-1\right\}
\end{aligned}
$$

where $d$ is the degrees of freedom and $s$ is the standard error for the slope and $t_{d}^{-1}(q)$ is the qth quantile of a $t$ distribution with d degrees of freedom. The $P$ value for a 2-sided test for which the true APC is 0 is calculated based on a distribution.

The analysis was performed for all children aged < 5 years, followed by a stratified analysis by age group, 
residence area and region. We did not perform a sexspecific analysis or other specific analyses because the data published in the Ministry of Health report only included age group. The APCs before and after the joinpoint for the different regions were represented using the Linked Micromaps software.

\section{Ethical approval and consent to participate}

This study was approved by the Ethics Committee of the Faculty of Medicine and Pharmacy, Mohamed V University, Rabat. All data are presented in aggregate form without any individual identification in the report of the Ministry of Health of Morocco, which is openly available on the Ministry of Health website (16).

\section{Results}

During 2005-2014, 2338282 cases of ALRI occurred in Morocco (Table 1). Most cases were children aged 1 to $<5$ years $(1545357,66.1 \%)$ and occurred in urban areas (1 $401437,60.0 \%$ ).

The incidence of ALRI increased significantly between 2005 and 2011: by $3.08 \%$ in children aged $<5$ years ( $\mathrm{APC}=3.08,95 \% \mathrm{CI}: 0.7-5.6$ ) (Figure 1), by $3.24 \%$ in children aged 1 to $<5$ years $(\mathrm{APC}=3.24,95 \%$ CI: 0.6-6.0)

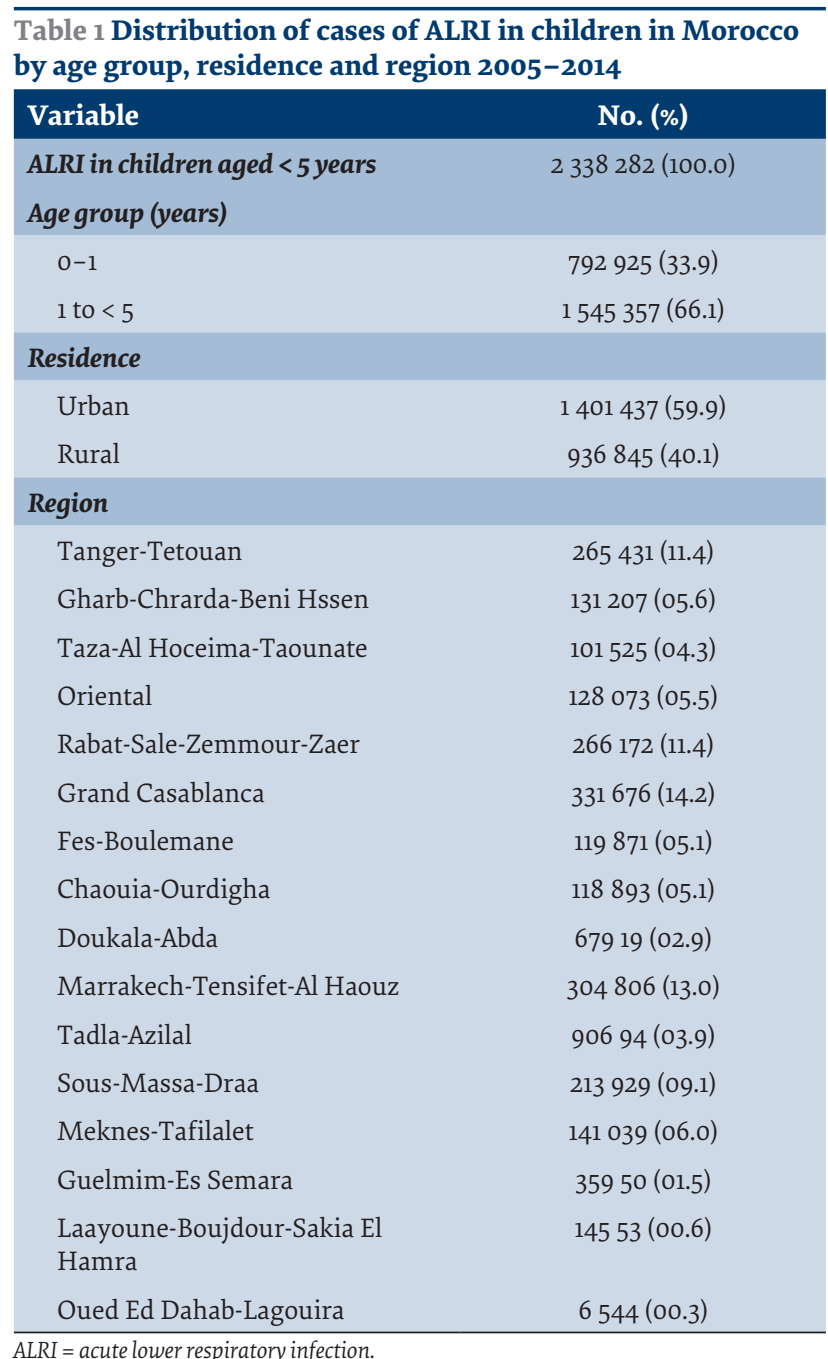

Figure 1 Trend in the incidence of acute lower respiratory infections in children $<5$ years, Morocco, 2005-2014.

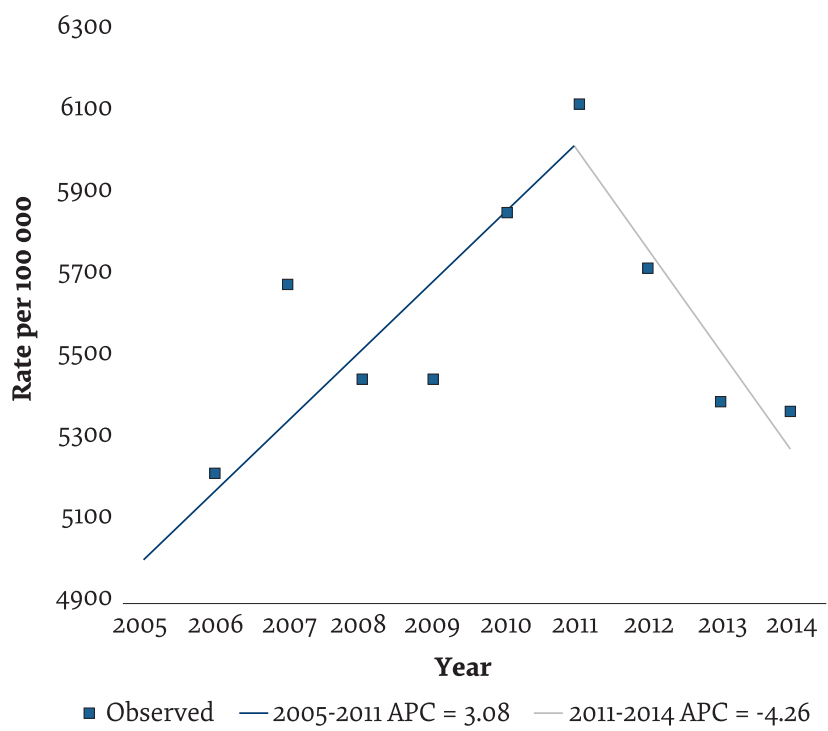

$A P C=$ annual percentage change.

and by $4.27 \%$ in urban areas (APC $=4.27,95 \%$ CI: $1.3-7.6)$ (Figure 2A). However, the incidence was relatively stable after 2011 as the observed trends were not statistically significant, although the incidence decreased from 2011 to 2014 by $4.26 \%$ in children aged $<5$ years $(\mathrm{APC}=-4.26$, 95\% CI: -10.9 to 2.8 ) (Figure 1), by $3.57 \%$ in children aged 1 to $<5$ years $(\mathrm{APC}=-3.57,95 \% \mathrm{CI}:-10.7$ to 4.1$)$ and by $5.41 \%$ in urban areas (APC $=-5.41,95 \%$ CI: -13.6 to 3.3 ) (Figure 2A). The joinpoints corresponded to the year 2011 (95\% CI: 2007-2012) for children aged < 5 years, children aged 1 to $<5$ years and in urban areas (Table 2).

The incidence of ALRI increased from 2005 to 2011: by $2.17 \%$ in children aged $<1$ year $(\mathrm{APC}=2.17,95 \% \mathrm{CI}:-0.2$ to 4.5 ) and by $0.99 \%$ in rural residence (APC $=0.99,95 \%$ CI: -1.4 to 3.4) (Figure 2B) but these increases were not significant. The incidence decreased from 2011 to 2014: by $5.60 \%$ in children aged $<1$ year $(\mathrm{APC}=-5.60,95 \% \mathrm{CI}:-11.7$ to 1.0 ) and by $2.82 \%$ in rural residence (APC $=-2.82,95 \%$ CI: -9.3 to 4.3 ) (Figure 2B) but these decreases were also not significant. The joinpoints corresponded to the year 2011 (95\% CI: 2007-2012) for children aged < 1 year and in rural residence (Table 2).

In 8 out of 16 regions, there was an increase in the incidence of ALRI before the joinpoint, a significant increase in 3 of them, and a decrease in the incidence after this joinpoint in 12 of 16 regions, a significant decrease in 1 of them (Figure 3, Table 2). The 95\% CI of these 8 joinpoints included the period following PVC introduction (Table 2).

\section{Discussion}

Our results showed a break in the trend of increasing incidence of ALRI in children aged < 5 years in 2011 (1 year after introduction of the PCV in the national immunization programme in Morocco). The incidence increased significantly before the joinponit (positive APC) and 
Figure 2 Trend in the incidence of acute lower respiratory infections in children < 5 years by residence, Morocco, 2005-2014: (A) urban residence, (B) rural residence

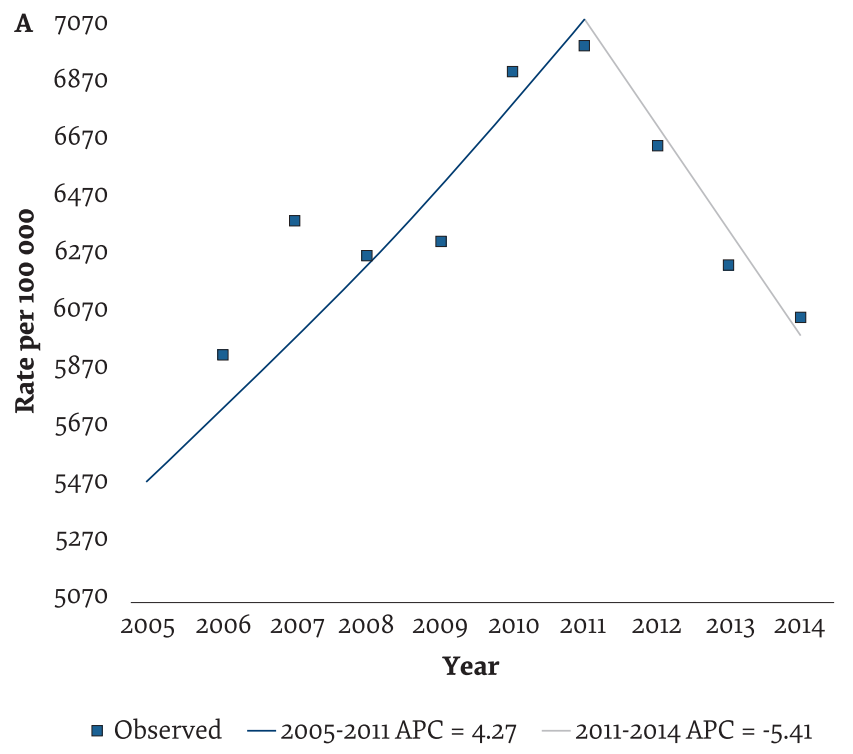

$A P C=$ annual percentage change.

decreased after the joinpoint (negative APC). This decrease could have been due to multiple factors such as a training programme for diagnosis of ALRI, or changes in health system practices. We hypothesize that this de-

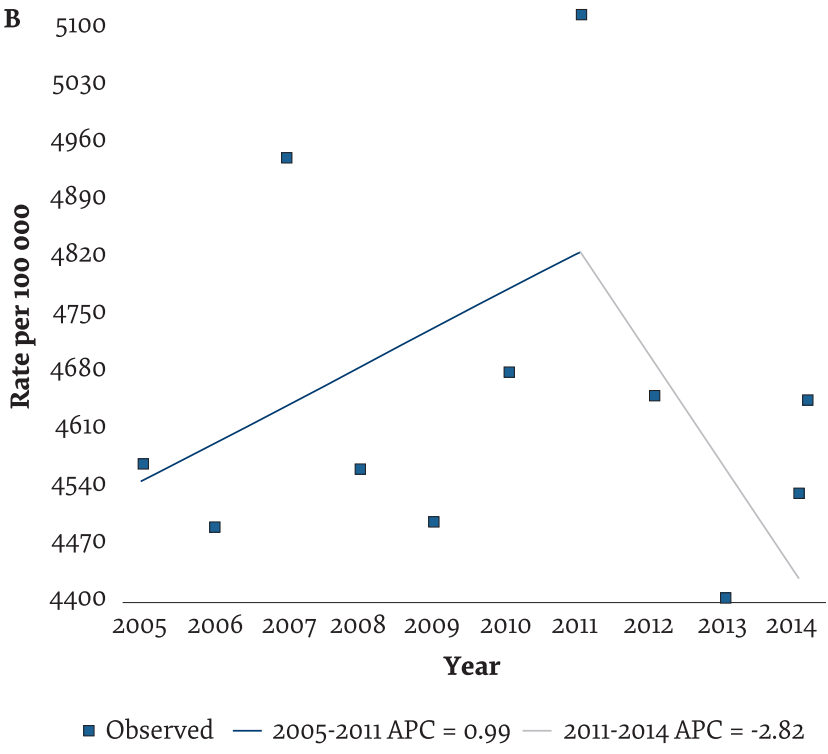

crease could also be explained by the introduction in 2010 of the PCV in the national immunization programme in Morocco. We observed a significant decreasing trend or stabilization in incidence of ALRI, in children aged 1 to <

\begin{tabular}{|c|c|c|c|c|}
\hline Variable & $\begin{array}{l}\text { APC before } \\
\text { joinpoint }\end{array}$ & $\begin{array}{l}\text { APC after } \\
\text { joinpoint }\end{array}$ & Joinpoint & $95 \% \mathrm{CI}$ \\
\hline Children aged < 5 years & $3.08^{\mathrm{a}}$ & -4.26 & 2011 & $2007-2012$ \\
\hline \multicolumn{5}{|l|}{ Age group (years) } \\
\hline $0-1$ & 2.17 & -5.60 & 2011 & $2009-2012$ \\
\hline 1 to $<5$ & $3.24^{\mathrm{a}}$ & -3.57 & 2011 & $2007-2012$ \\
\hline \multicolumn{5}{|l|}{ Residence } \\
\hline Urban & $4.27^{\mathrm{a}}$ & -5.41 & 2011 & $2007-2012$ \\
\hline Rural & 0.99 & -2.82 & 2011 & 2007-2012 \\
\hline \multicolumn{5}{|l|}{ Region } \\
\hline Tanger-Tetouan & 13.20 & -0.71 & 2007 & $2007-2012$ \\
\hline Gharb-Chrarda-Beni Hssen & 3.32 & $-4.45^{a}$ & 2007 & $2007-2012$ \\
\hline Taza-Al Hoceima-Taounate & 6.39 & -13.54 & 2012 & $2007-2012$ \\
\hline Oriental & 0.64 & -4.02 & 2011 & $2007-2012$ \\
\hline Rabat-Sale-Zemmour-Zaer & $20.66^{a}$ & $1.8 \mathrm{o}^{\mathrm{a}}$ & 2007 & $2007-2008$ \\
\hline Grand Casablanca & $28.84^{\mathrm{a}}$ & -1.15 & 2008 & $2007-2012$ \\
\hline Fes-Boulemane & $6.36^{\mathrm{a}}$ & -13.53 & 2012 & $2008-2012$ \\
\hline Chaouia-Ourdigha & -1.87 & -10.96 & 2011 & $2007-2012$ \\
\hline Doukala-Abda & -6.72 & 0.67 & 2009 & $2007-2012$ \\
\hline Marrakech-Tensifet-Al Haouz & 1.40 & -1.73 & 2012 & $2007-2012$ \\
\hline Tadla-Azilal & 24.75 & -3.20 & 2007 & $2007-2009$ \\
\hline Sous-Massa-Draa & -0.39 & -8.43 & 2011 & $2008-2012$ \\
\hline Meknes-Tafilalet & 1.86 & -6.91 & 2011 & $2007-2012$ \\
\hline Guelmim-Es Semara & $-7.30^{\mathrm{a}}$ & 17.35 & 2011 & $2008-2012$ \\
\hline Laayoune-Boujdour-Sakia El Hamra & $-16.59^{\mathrm{a}}$ & $27.57^{\mathrm{a}}$ & 2010 & $2009-2012$ \\
\hline Oued Ed Dahab-Lagouira & $13.49^{\mathrm{a}}$ & -6.59 & 2010 & $2007-2012$ \\
\hline
\end{tabular}

${ }^{a}$ Annual percentage change is statistically different from 0 at $=0.05$.

$A P C=$ annual percentage change $C I=$ confidence interval. 
Figure 3 Annual percentage change (APC) before and after joinpoints by region, Morocco, 2005-2014.

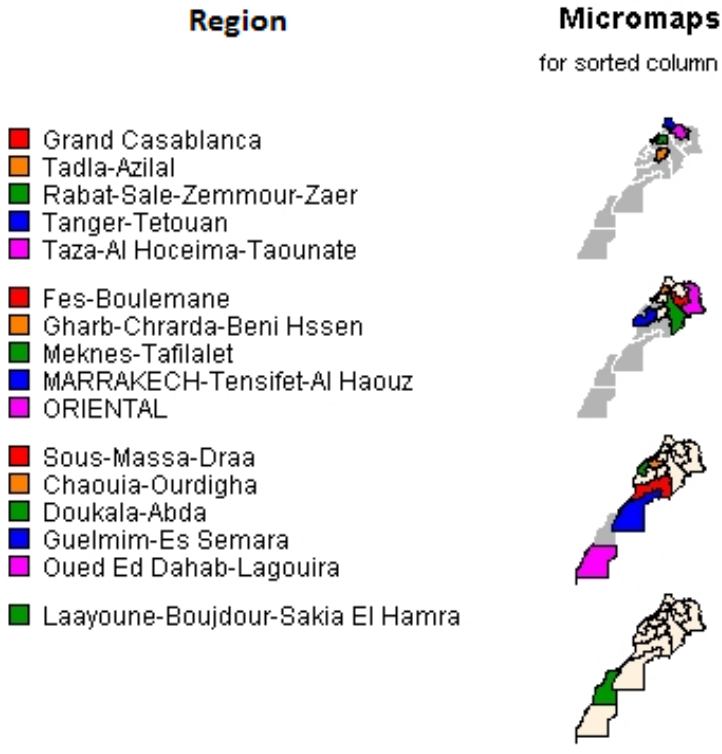

5 years, in urban areas, and in 3 of 16 regions, which were among the most populated. The $95 \%$ CI of joinpoints included the postvaccination period. This suggests efficacy of the PCV in preventing ALRI. The difference in trend was more evident in urban than rural areas and children aged 1 to $<5$ years compared with $<1$ year because the number of cases was more important in these 2 groups, so the power was sufficient to show a significant difference.

Several studies have highlighted the effect of introduction of PCV in reducing respiratory infections (18-21). Furthermore, randomized clinical trials have shown that PCV prevents pneumonia (22-24). However, efficacy estimates have varied according to the case definition of pneumonia. Vaccine efficacy against clinically diagnosed pneumonia was $6 \%$ for 7 -valent PCV in the Northern California Kaiser Permanente trial (22) and $7 \%$ for a 9-valent PCV in a Gambian trial (23). A trial in South Africa also using a 9-valent PCV reported efficacy of $16 \%$ for pneumonia admissions (24). Vaccine efficacy estimates were consistently higher when radiological confirmation was included as part of the case definition - $18 \%$ in the Kaiser Permanente trial (22), $17 \%$ in the South African trial (24) and 37\% in the Gambian trial (23).

There were some limitations to our study. (1) The decrease in incidence 1 year after PCV was introduced was not significant, except in Gharb-Chrarda-Beni Hssen. This could have been due to lower statistical power because of limited time (only 3 years) after the joinpoint. (2) The analytical method used was exploratory and did not take into account any other factors that may influence the trend in the incidence of ALRI; in particular, the level of regional implementation of the programme to control ALRI in children. Further analysis, including interrupted time series analysis with a multivariate approach, could be used to answer this question more thoroughly. (3) The surveillance system in Morocco is managed exclusively by the Ministry of Health and it is mostly based on

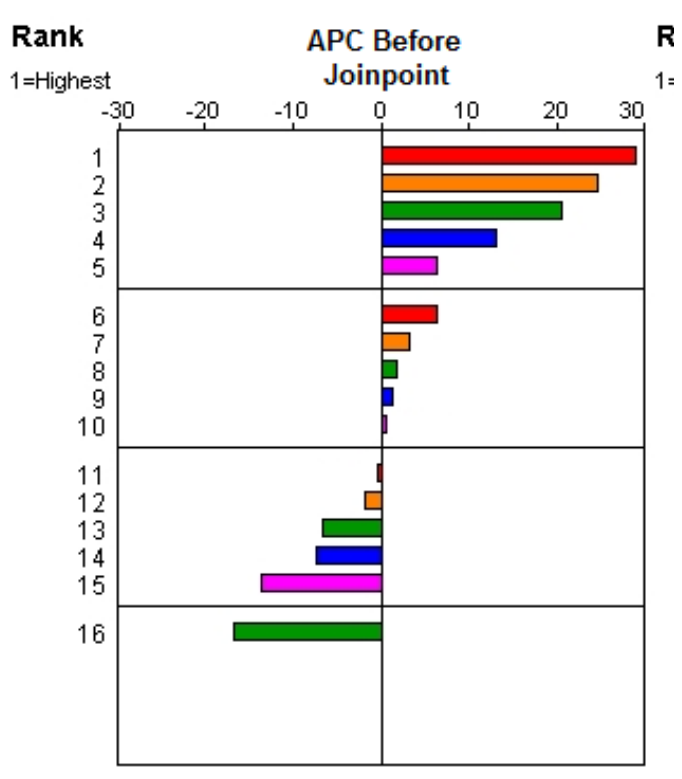

the public sector. While its representativeness could be questioned, the trends shown by the data collected are not biased because there was no change in the surveillance organization during the study period (4). Cases of ALRI are based on passive surveillance data and this may result in under-reporting. However, this bias would have a small effect on our results since underreporting would persist over time (5). The definition of ALRI was based only on clinical criteria, we did not have information about the causative agents, and ALRI can be caused by bacteria and viruses other than S. pneumoniae (6). The calculated incidence was biased because cases counted in the numerator corresponded to those notified only in the public sector (7). We did not include a control group for assessing our results (8). In GuelmimEssemara, Laayoune-Boujdour-Sakia El Hamra and Oued Ed Dahab-Lagouira, there was a significant decreasing trend in the incidence of ALRI before the joinpoint of PCV introduction and this was stable after the joinpoint, except for Laayoune-Boujdour-Sakia El Hamra. The CI of the joinpoint includes the postvaccination period. These southern regions are desert areas and are less populated. This observation may be also due to an increase in the number of reports following awareness campaigns or other factors favouring a rise in ALRI cases, especially a decline in breastfeeding in these regions.

In spite of these limitations, our study is important because it is the first national study in Morocco to assess the effect of PCV introduction on the trend in the incidence of ALRI, using national epidemiological surveillance data.

\section{Conclusion}

Our results suggest that PCV has influenced the trends in incidence of ALRI in Morocco. However, the analytical method used cannot provide strong evidence about this relationship and this hypothesis must be explored by further studies. 


\section{Acknowledgement}

We are grateful to the Directorate of Panning and Financial Resources which helped to create the database.

\section{Funding: None.}

Competing interests: None declared.

\section{Mesure de l'évolution de l'infection aiguë respiratoire basse chez l'enfant de moins de cinq ans au Maroc de 2005 à 2014}

\section{Résumé}

Contexte: L'infection aiguë respiratoire basse constitue une cause majeure de décès chez les enfants de moins cinq ans au Maroc. Le vaccin antipneumococcique conjugué 13-valent (VPC 13) a été introduit dans le cadre du Programme de vaccination national du Maroc en 2010.

Objectifs : Mesurer l'évolution de l'incidence de l'infection aiguë respiratoire basse chez les enfants de moins de cinq ans durant la période comprise entre 2005 et 2014 au Maroc.

Méthodes: Des données sur l'infection aiguë respiratoire basse chez les enfants de moins de cinq ans ont été obtenues à partir des données publiées chaque année par le ministère de la Santé marocain. Nous avons recouru à l'analyse de régression joinpoint pour estimer la tendance de l'incidence de ce type d'infections pendant la période de l'étude.

Résultats : L'incidence de l'infection aiguë respiratoire basse a augmenté de manière significative entre 2005 et 2011 de 3,08 \% par an chez les enfants de moins de cinq ans et de 3,24\% par an chez les enfants dont l'âge était compris entre un et moins de cinq ans. Cependant, l'incidence était stable après 2011, les tendances observées n'étant pas significatives, bien que l'incidence ait diminué de 4,26\% par an entre 2011 et 2014 chez les enfants de moins de cinq ans, de 3,57 \% par an chez les enfants dont l'âge était compris entre un et moins de cinq ans et de 5,14 \% par an dans les zones urbaines.

Conclusions : Nos résultats suggèrent une influence probable du VPC 13 sur l'évolution de l'incidence de l'infection aiguë respiratoire basse au Maroc.

$$
\text { تطور عدوى الجهاز التنفي السفلي الحادة في الأطفال الذين تقل أعمارهم عن } 500 \text { سنوات في المغرب في الفترة بين عامي }
$$

$$
\text { ندى بناني خيتا، رشيد رزين، مجدولين أوبتل، عبد الإله المرنيسي، ليلى لحلوح، عهاد شرقاوي، عزيزة لغفوري، مصطفى مرابط، رضوان أبو كال }
$$

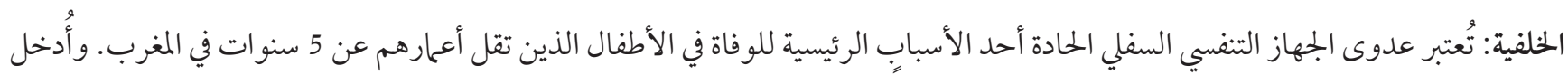

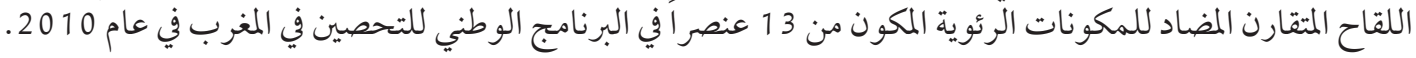

الأهداف: هدفت هذه الدراسة إلى تحري الاتجاه السائد في معدل الإصابة بعدوى الجهاز التنفسي السفلي الحادة في الأطفال الذين تقل أعمارهم عن

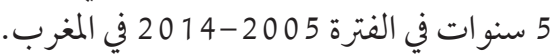

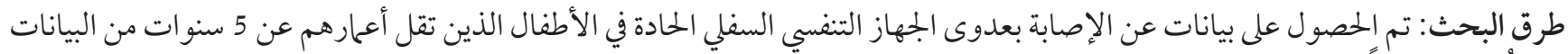

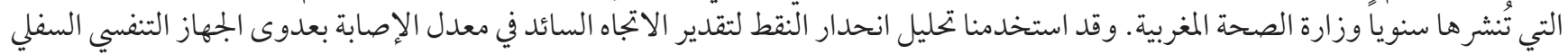
الحادة خلال فترة الدراسة.

النتائج: ارتفع معدل الإصابة بعدوى الجهاز التنفسي السفلي الحادة ارتفاعاً كبيراً في الفترة بين عامي

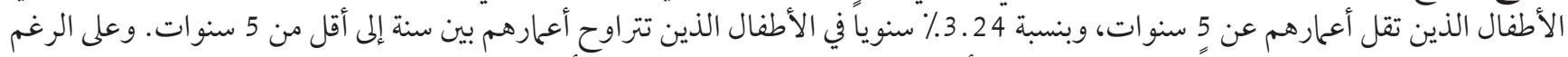

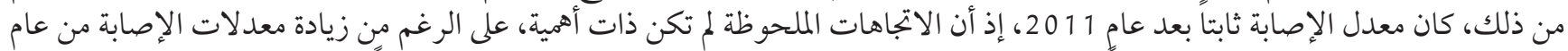

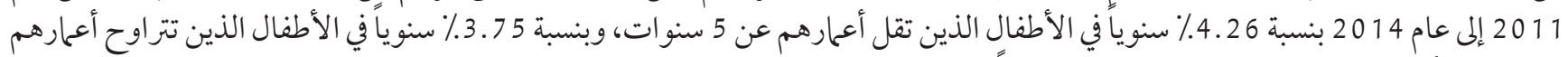

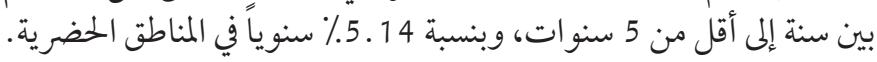
الاستنتاجات: تُشير نتائجنا إلى تأثير محتمل للقاح المتقارن المضاد للمكونات الرئوية على اتجاه معدل الإصابة بعدوى الجهاز التنفسي السفلي الحادة في المغرب. 


\section{References}

1. Rose M, Zielen S. Impact of infant immunization programs with pneumococcal conjugate vaccine in Europe. Expert Rev Vaccines 2009 Oct;8(10):1351-64. http://dx.doi.org/10.1586/erv.09.78 PMID:19803758

2. Wahl B, O’Brien KL, Greenbaum A, Majumder A, Liu L, Chu Y, et al. Burden of Streptococcus pneumoniae and Haemophilus influenzae type $b$ disease in children in the era of conjugate vaccines: global, regional, and national estimates for 2000-15. Lancet Glob Health. 2018 Jul:6(7):e744-57. http://dx.doi.org/10.1016/S2214-109X(18)30247-X PMID:29903376

3. Izu A, Solomon F, Nzenze SA, Mudau A, Zell E, O’Brien KL, et al. Pneumococcal conjugate vaccines and hospitalization of children for pneumonia: a time-series analysis, South Africa, 2006-2014. Bull World Health Organ. 2017 Sep 1;95(9):618-28. http:// dx.doi.org/10.2471/BLT.16.187849 PMID:28867842

4. Simonsen L, Taylor RJ, Young-Xu Y, Haber M, May L, Klugman KP. Impact of pneumococcal conjugate vaccination of infants on pneumonia and influenza hospitalization and mortality in all age groups in the United States. MBio. 2011 Jan 25;2(1):e00309-10. http://dx.doi.org/10.1128/mBio.00309-10 PMID:21264063

5. Poehling KA, Talbot TR, Griffin MR, Craig AS, Whitney CG, Zell E, et al. Invasive pneumococcal disease among infants before and after introduction of pneumococcal conjugate vaccine. JAMA 2006 Apr 12;295(14):1668-74. http://dx.doi.org/10.1001/ jama.295.14.1668 PMID:16609088

6. Pilishvili T, Lexau C, Farley MM, Hadler J, Harrison LH, Bennett NM. Sustained reductions in invasive pneumococcal disease in the era of conjugate vaccine. J Infect Dis. 2010 Jan 1;201(1):32-41. http://dx.doi.org/10.1086/648593 PMID:19947881

7. Lepoutre A, Varon E, Georges S, Gutmann L, Lévy-Bruhl D. Impact of infant pneumococcal vaccination on invasive pneumococcal diseases in France, 2001-2006. Eurosurveillance 2008 Aug 28;13(35):27-39. http://dx.doi.org/10.2807/ese.13.35.18962-en PMID:18761883

8. Afonso ET, Minamisava R, Bierrenbach AL, Cortez Escalante JJ, Alencar AP, Domingues CM, et al. Effect of 10-valent pneumococcal vaccine on pneumonia among children, Brazil. Emerg Infect Dis 2013 Apr;19(4):589-97. http://dx.doi.org/10.3201/ eid1904.121198

9. Guide du Programme National d'Immunisation [website]. Royaume du Maroc, Ministère de la Santé; 2018 (http://www.sante. gov.ma/Publications/Guides-Manuels/Pages/default.aspx, accessed 3 September 2020) (in French).

10. Prise en charge intégrée de l'enfant. [website]. Royaume du Maroc, Ministère de la santé; 2016 (https://www.sante.gov.ma/Publications/Guides-Manuels/Pages/default.aspx, accessed August 26 2020) (in French).

11. Jroundi I, Mahraoui C, Benmessaoud R, Moraleda C, Munoz Almagro C, Seffar M, et al. Streptococcus pneumoniae carriage among healthy and sick pediatric patients before the generalized implementation of the 13-valent pneumococcal vaccine in Morocco from 2010 to 2011. J Infect Public Health. 2017 mar-Apr;10(2):165-70. https://doi.org/10.1016/j.jiph.2016.02.012

12. Diawara I, Zerouali K, Elmdaghri N, Abid A. A case report of parapneumonic pleural effusion caused by Streptococcus pneumoniae serotype 19A in a child immunized with 13- valent conjugate pneumococcal vaccine. BMC Pediatr. 2017 Apr 27;17(1):114. http:// dx.doi.org/10.1186/s12887-017-0872-2 PMID:28449653

13. Portail National des Collectivités Locales. Nouveau découpage territorial du Royaume [website] Royaume du Maroc, Ministère de l'Intérieur (http://www.pncl.gov.ma/fr/News/Alaune/Pages/Nouveau-d\%C3\%A9coupage-r\%C3\%Aggional-du-Royaume-.aspx, accessed 3 Septemeber 2020) (in French).

14. Portail National des Collectivités Locales. 29 juillet 2011: vers une nouvelle étape de développement de la décentralisation et de la régionalisation au Maroc [website]. Royaume du Maroc, Ministère de l'Intérieur; 2011 (http://www.pncl.gov.ma/fr/ Decentralisation/Pages/29-juillet-2011--vers-une-nouvelle-\%C3\%A9tape-de-d\%C3\%A9veloppement-de-la-d\%C3\%A9centralisation-et-de-la-r\%C3\%Aggionalisation-au-Maroc.aspx, accessed 3 September 2020) (in French).

15. Direction de la statistique. Recensement général de l'habitat et de la population 2014 [website]. Rabat: Haut Commissariat au Plan (https://rgph2014.hcp.ma/downloads/Resultats-RGPH-2014_t18649.html, accessed 26 August 2020) (in French)

16. Santé en chiffre [website] Royaume du Maroc, Ministère de la santé. http://www.sante.gov.ma/Publications/Etudes_enquete/ Pages/default.aspx, accessed 3 September 2020) (in French).

17. Statistical notes [website]. National Cancer Institute. Division of Cancer Control and Population Sciences (https://surveillance. cancer.gov/help/joinpoint/statistical-notes, accessed 3 September 2020).

18. Grijalva CG, Nuorti JP, Arbogast PG, Martin SW, Edwards KM, Griffin MR. Decline in pneumonia admissions after routine childhood immunisation with pneumococcal conjugate vaccine in the USA: a time-series analysis. Lancet. $2007 \mathrm{Apr}$ 7;369(9568):1179-86. http://dx.doi.org/10.1016/So140-6736(07)60564-9 PMID:17416262

19. Mollendorf CV, Tempia S, Gottberg AV, Meiring S, Quan V, Feldman C, et al. Estimated severe pneumococcal disease cases and deaths before and after pneumococcal conjugate vaccine introduction in children younger than 5 years in South Africa. PLoS One 2017 Jul 3;12(7):e0179905. http://dx.doi.org/10.1371/journal.pone.0179905 PMID:28671978

20. Noel G, Viudes G, Laporte R, and Minodier P. Evaluation of the impact of pneumococcal conjugate vaccine on pediatric community-acquired pneumonia using an emergency database system. J Pediatric Infect Dis Soc. 2017 Jun;6(2):129-33. https://doi. org/10.1093/jpids/piw019 
21. Chang H, Bednarczyk RA, Becker ER, Hockenberry JM, Weiss PS, Orenstein WA, et al. Trends in U.S. hospitalizations and inpatient deaths from pneumonia and influenza,1996-2011. Vaccine. 2016 Jan 20;34(4):486-94. http://dx.doi.org/10.1016/j.vaccine.2015.12.003 PMID:26706275

22. Black SB, Shinefield HR, Ling S, Hansen J, Fireman B, Spring D, et al. Effectiveness of heptavalent pneumococcal conjugate vaccine in children younger than five years for prevention of pneumonia. Pediatr Infect Dis J. 2002 Sep;21(9):810-15. http://dx.doi. org/10.1097/00006454-200209000-00005 PMID:12352800

23. Cutts FT, Zaman SM, Enwere G, Jaffar S, Levine OS, Okoko JB, et al. Efficacy of nine-valent pneumococcal conjugate vaccine against pneumonia and invasive pneumococcal disease in The Gambia: randomised, double-blind, placebo-controlled trial. Lancet. 2005 Mar 26-Apr 1;365(9465):1139-46. http://dx.doi.org/10.1016/So140-6736(05)71876-6 PMID:15794968

24. Klugman KP, Madhi SA, Huebner RE, Kohberger R, Mbelle N, Pierce N, et al. A trial of a 9-valent pneumococcal conjugate vaccine in children with and those without HIV infection. N Engl J Med. 2003 Oct 2;349(14):1341-8. http://dx.doi.org/10.1056/NEJMoa035060 PMID:14523142 